Canadian Journal of Higher Education Revue canadienne d'enseignement supérieur

Volume 44, No. 1, 2014, pages 95 - 107

\title{
Community service-learning and cultural-historical activity theory
}

\author{
Alison Taylor \\ University of Alberta
}

\begin{abstract}
This paper explores the potential of cultural-historical activity theory (CHAT), to provide new insights into community service-learning (CSL) in higher education. While CSL literature acknowledges the influences of John Dewey and Paolo Freire, discussion of the potential contribution of cultural-historical activity theory, rooted in the work of Russian psychologist Lev Vygotsky, is noticeably absent. This paper addresses this gap by examining four assumptions associated with activity theory: the rejection of a theory/practice divide, the development of knowledge as a social collaborative activity, the focus on contradictions in and across activity systems, and the interventionist approach aimed at transformation.
\end{abstract}

\section{Résumé}

Cet article explore le potentiel de la théorie de l'activité culturelle et historique (CHAT) afin de donner un nouvel aperçu de l'apprentissage par le service communautaire (ASC) dans un contexte universitaire. Bien que des études sur le sujet de l'ASC reconnaissent les influences de John Dewey et de Paolo Freire, l'absence d'une discussion portant sur la contribution potentielle de la CHAT, enracinée dans l'œuvre du psychologue russe Lev Vygotsky, est flagrante. Le présent article comble cette lacune en examinant quatre hypothèses liées à la CHAT : le rejet d'une ligne de partage entre la théorie et la pratique; le développement des connaissances comme activité sociale et collaborative; la convergence des contradictions à l'intérieur des systèmes d'activités et entre eux; ainsi qu'une approche interventionniste visant la transformation. 


\section{Introduction}

Increasingly, universities in North America are implementing programs like community service-learning (CSL) to strengthen their connections with local communities. CSL has been an educational practice and philosophy for several decades in the United States, and has been taken up in Canada more recently (Chambers, 2009). The number of CSL programs in Canadian colleges and universities grew from six in 2005 to around 30 by 2009 (Charbonneau, 2009). Service-learning has been described as part of a larger movement for civic engagement in higher education in the US (Saltmarsh, Hartley, \& Clayton, 2009) and as a component of community-university engagement (CUE) in Canada (Jackson, 2008).

CSL research has been situated theoretically in literatures about experiential education, social learning, student development, and liberatory education (Chambers, 2009). But references to sociocultural learning theories like cultural-historical activity theory (CHAT) are noticeably absent in both Chambers (2009) and in the work of commonly cited U.S. writers (e.g., Dan Butin, Barbara Holland). This paper addresses this gap by examining the potential contributions of CHAT to discussions about CSL as a form of pedagogy in higher education, and by developing an analytical framework that could be used by students and instructors in community-based inquiry. CHAT is appealing because, like other approaches embedded in a dialectical tradition, it aims to understand how to create the conditions for full human development (Chailkin, 2012). Following this introduction, I discuss community service-learning within higher education and the conceptual framework provided by CHAT.

\section{What Is Service-Learning?}

During the last quarter of the $20^{\text {th }}$ century, community service-learning emerged as a "popular and powerful educational philosophy and pedagogical approach that integrated academic subject matter with applied social engagement and critical reflection" (Chambers, 2009, p. 79). In curricular CSL, students participate in an experiential learning activity with and for a community organization, and they reflect on that activity to gain "further understanding of course content, a broader appreciation of the discipline, and an enhanced sense of civic responsibility" (Bringle \& Hatcher, 1996, p. 222). Service-learning programs are located around the middle of a continuum that stretches from volunteerism (closer to the "service" end) to internships and field experience (closer to the "learning" end). CSL programs sit in the middle of this continuum because they attempt to strike a balance between service and learning aims, and to equally benefit both the provider and recipient of the service (Furco, 1996). The partners involved in CSL (usually not-for-profit and voluntary sector organizations) and the goals of learning (usually focused on social and educational as well as vocational goals) also differ from other experiential learning programs.

Butin (2007) presents four models of community engagement (including CSL): technical, cultural, political, and antifoundational. The technical perspective emphasizes questions of efficiency, quality, efficacy, and sustainability of engagement initiatives such as community service-learning. Cultural perspectives privilege the affective, ethical, and formative aspects, while political perspectives are concerned with issues of competing constituencies and their manifestations. The antifoundational perspective begins from the premise that truths are always local, contingent, and intersubjective, and therefore 
CSL provides opportunities for rethinking our taken-for-granted world. Butin asserts that as long as each discipline meets its own academic standards for legitimate teaching and scholarship, different forms of CSL can flourish.

Mitchell (2008) identifies two similar models of service-learning described as traditional and critical. While the traditional approach is described as emphasizing service without attention to systems of inequality, a critical approach aims to "dismantle structures of injustice" (p. 50). The models identified by Butin and Mitchell raise important questions about the diverse ways in which CSL has been framed conceptually and the implications of these approaches.

\section{The Conceptual Framing of Service-Learning}

In presenting a multi-level conceptual framework intended to guide initiatives in Canadian educational institutions, Chambers (2009) links different CSL approaches to a continuum of aims for programs, which range from philanthropy to social transformation. John Dewey is seen as a key contributor to service-learning theory because of his pragmatic philosophy, his concerns about democratic participation, and his student-centered educational theory (Deans, 1999). Service-learning literature embraces Dewey's idea that effective learning requires contextualization through application and experience, and his view that education as a social phenomenon serves to reinforce the aims and methods of society (e.g., Fredericksen, 2000; Hugg \& Wurdinger, 2007). Researchers commonly justify programs using Dewey's idea that education and learning are processes of growth, characterized by active experimentation and reflective thought. Social psychologist, David Kolb's characterization of experiential education as a process whereby knowledge is created through the transformation of experience has also been influential (Kolb, 1984). Kolb's theory is linked to the tenets of CSL as a learning approach that requires both action and reflection (Chambers, 2009).

In addition to Dewey and Kolb, Brazilian educator Paolo Freire's ideas about liberatory education have also provided a theoretical anchor for many service-learning programs and courses (Chambers, 2009; Chovanec et al. 2012; Kajner et al., 2013). Freire advocated learning situations that are collaborative, active, community oriented, and grounded in the culture of the student (Deans, 1999). While both Dewey and Freire saw development (of human nature) as a dynamic and fluid process taking place at the intersection of individuals and their worlds, Freire's goals included a revolutionary restructuring of the political and economic status quo while Dewey promoted incremental social reconstruction (Stetsenko, 2008; Deans, 1999).

Although Chambers' (2009) and Butin's (e.g., 2006, 2010) works provide useful overviews of the CSL literature, discussion of the potential contribution of CHAT rooted in the work of Russian psychologist Lev Vygotsky is noticeably absent. This is unfortunate, since Vygotsky's project and CHAT support the argument that service-learning and other forms of experiential learning are not only important but also necessary in today's world, where the idea of knowledge as an abstract and autonomous reality detached from issues of real practice, history, and politics is increasingly untenable (cf. Stetsenko \& Arievitch, 2004). CHAT has been described as a "cross-disciplinary framework for studying how humans purposefully transform natural and social reality, including themselves, as an ongoing cultural and historically situated, materially and socially mediated process" (Roth, Radford, \& LaCroix, 2012, p. 1). 


\section{Vygotsky and CHAT}

In opposition to the idea of "mind as container," Jean Piaget, John Dewey, and Lev Vygotsky share the view that social and psychological phenomena exist in the realm of relations and interactions, and they see learning as an active endeavor rather than as the passive transmission of knowledge (Fenwick, Edwards, \& Sawchuk, 2011). In contrast to the Cartesian dichotomy of subject and object-person and world-socio-cultural theories offer a relational ontology. Human action is understood as "the foundation and core reality of development and learning, mind and knowledge"-individuals learn through acting "in and on their world" (Stetsenko, 2008, p. 479; emphasis added).

Vygotsky and his followers proposed that human activity-"material, practical, and always by necessity social, collaborative processes aimed at transforming the world"-is the basic form of human life and relation to the world (Stetsenko, 2008, p. 483). In the 1930s, Vygotsky's focus on "object-oriented action mediated by cultural tools and signs" was a key contribution to the development of what is now referred to as first-generation activity theory (Engeström \& Miettinen, 1999, p. 4). He, along with Leont'ev and Luria, studied the historical, political, and cultural processes of learning and development. In the second generation of CHAT in the 1970s, Leont'ev and others brought more focus to collective activity, in contrast to Vygtosky's earlier emphasis on individual action (Neiwolny \& Wilson, 2009). In the third generation starting in the 1980s, Engeström elaborated a broader concept of activity to include interacting activity systems, and he applied this broader framework to new phenomena (Engeström \& Miettinen, 1999; Lompscher, 2006).

The focus on activity systems directs attention to who is carrying out activities (division of labour), what tools are at their disposal, which cultural norms and rules govern their performance, and what are the desired outcomes. In a formal teaching-learning context, this may involve introducing students to knowledge as a cultural tool for solving problems encountered in practice and requiring them to reconstruct knowledge through their own activity (Stetsenko, 2010). Revealing activities hidden behind abstract concepts makes these same concepts meaningful, while also transforming knowledge into something that is both tangible and practical.

CHAT assumes that the experience and knowledge of previous generations-evident in objects, norms, values, and other aspects of culture-mediates human interactions with the world (Lompscher, 2006). People transform their conditions, aiming to produce and reproduce conditions for their life (Chailken, 2012); learning thus involves an expansion of an individual's realm of possible actions (Roth et al., 2012). CHAT has much potential for educators because of this focus on development and learning practices. Its interdisciplinary approach ${ }^{1}$ also holds promise for the development of new conceptual tools for tackling important theoretical and methodological questions in the social sciences (Engeström \& Miettinen, 1999; Sawchuk et al., 2006). CHAT studies examine the histories of systems and relations among material artifacts as well as their divisions of labour, cultural norms, and rules; in short, "how things came to be as they are, how they came to be viewed in ways that they are, and how they are appropriated in the course of developmental trajectories" (Fenwick et al., 2011, p. 9).

The following key features of CHAT are helpful for analyzing the place of CSL in universities and provide an analytical framework for students and instructors to use in community-based inquiry: 
- rejection of theory/practice divide

- assumption that the development of knowledge is a social collaborative activity

- interest in examining overlapping activity systems with a focus on contradictions

- interventionist approach aimed at transformation as opposed to adaptation These four features are elaborated below.

\section{Rejection of Theory/Practice Divide}

CHAT encourages a dialectical approach that challenges mutually exclusive categories like individual-collective, mind-body, subject-object, and structure-agency (Roth \& Lee, 2007). The idea that human activity is culturally mediated challenges the boundaries of categories like these, demonstrating their co-constitution (cf. Niewolny \& Wilson, 2009; Sawchuk et al., 2006). For example, as opposed to the dichotomy between theory and practice that is reproduced in much academic writing (including CSL research literature), CHAT represents theory and practice as different forms of knowledge. While everyday concepts help us make connections between natural phenomena and human experiences, theoretical concepts are seen as part of an organized system of interconnected concepts, based on generalizations that can be used to reveal aspects of the world not otherwise apparent (Guile, 2010). The process of learning thus involves using the generality contained by a theoretical concept to restructure our use of existing theoretical and everyday concepts.

The idea that learning is always contextual encourages us to pay greater attention to relationships between spheres of formal learning in school, college, or university and informal learning in other sites. In studies of experiential learning and school-to-work transition, societal activities are seen as a legitimate object of learning, rather than just texts, which are often perceived as isolated from the life activity of students (Miettinen, 1999). By structuring opportunities to move between school and work-activity systems, experiential learning programs like CSL enable "boundary crossing" by students across multiple spheres of activity and promote the development of connective skills (Akkerman \& Bakker 2011; Guile, 2010; Guile \& Griffiths, 2001).

The role of instructors is to frame community-learning projects for students, to provide developmental direction, and to help them integrate their in-class and out-of-class learning (cf. Beach, 1999; Miettinen \& Peisa, 2002). Community partners play an important role in supporting the development of students by acting as co-educators. The goal of CSL is thus to encourage the development of networks of learning that involve socially shared intellectual work around the joint accomplishment of tasks (cf. Miettinen \& Peisa, 2002). Rejecting the dichotomy between theory and practice is a critical first step in encouraging this kind of reciprocal and dynamic learning.

\section{Knowledge Development as a Social Collaborative Activityz}

The idea that learning can be effectively structured around cross-disciplinary networks of heterogeneous learners (Miettinen \& Peisa, 2002, p. 305) is consistent with the activity-theory assumption that we learn about our worlds and our possibilities through interaction with others and materials created by others (Edwards \& Mackenzie, 2005). Social, historical, and material relations underpin what we think of as individualized 
thinking, meaning, emotion, and higher mental functions (Fenwick et al., 2011). CHAT approaches thus provide insights into the relationship between knowledge as the possession of individuals and knowledge as the collective activity of communities of knowers (cf. Toulmin, 1999).

For example, Vygotsky's concept of zone of proximal development (ZPD) highlights the importance of a learner's interaction with more knowledgeable group members. ZPD refers to the distance between an individual's actual developmental level, as determined by independent problem solving, and the level of potential development that they could achieve through collaboration with more capable peers (Vygotsky, 1978). The possibility of new, more sophisticated actions in collective activity can also emerge when individuals collaborate with peers at the same level (Roth \& Lee, 2007). Engeström (1987, p. 174) broadened ZPD to include collective-activity systems, redefining it as "the distance between the everyday actions of individuals and the historically new form of societal activity that can be generated" from contradictions within activity systems. Thus, the study of an activity system becomes a "collective multi-voiced construction of its past, present, and future zones of proximal development" (Engeström \& Miettinen, 1999, p. 10).

These ideas help us think about curricular CSL (i.e., service-learning embedded in a university course) as a pedagogical approach that creates networks of learning with university and community members. Community partners play an important role in orientating students as they relocate themselves in activity systems with different objectives, rules, divisions of labour, and related artifacts (Guile \& Young, 2003). Similarly, an appropriate role for CSL units within universities involves supporting students, instructors, and community partners in negotiating the boundaries of multiple and sometimes contradictory activities (cf. Beach, 1999). The CHAT ideas discussed above stimulate instructors to think about their courses and students' experiential learning projects as opportunities for knowledge production that use the expertise potentially available through network collaboration (Miettinen \& Peisa, 2002).

\section{Contradictions In and AcrossActivity Systems}

In the third generation of CHAT, developed by Yrjo Engeström, contradictions between activity systems are seen as vital forces for change and development (Akkerman \& Bakker, 2011). Contradictions are defined as "historically accumulating structural tensions within and between activity systems," rather than problems or conflicts (Engeström, 2008). For example, in Roth and Lee's (2007) study of a Grade 7 environmental-science class project, the authors note the contradiction between the desire to produce quality work outside of the classroom as students engage with community members and the school requirements of completing curriculum within a particular time frame. When contradictions become exacerbated, questions emerge, actors struggle, negotiate and accommodate, learning occurs, and people and practices are transformed (Fenwick et al., 2011).

Versions of CHAT that begin from a closer reading of Marx's work ${ }^{2}$ highlight contradictions within and across activity systems that are rooted in capitalism (Livingstone, 2006; McDermott \& Lave, 2006; Sawchuk, 2006). For example, Livingstone (2006) reminds us about the fundamental contradiction between the continuing socialization of the forces of production (including knowledge production) and the privatized relations of ownership of the means of production. ${ }^{3}$ Similarly, Sawchuk et al., (2006) suggest that the 
credential-granting process in education is subject to the kind of contradictions between use-value and exchange-value that are inherent in the commodity form of knowledge production-"alienated learning produces the learner as a commodity" (McDermott \& Lave, 2006, p. 107).

This kind of analysis of contradictions within higher education activity systems provides a rationale for CSL as a pedagogy that increases students' control over their own learning and refocuses learning on the improvement of the social world, as opposed to the attainment of credentials (cf. Miettenen, 1999). The focus on contradictions also points to the transformative learning that is made possible through experiential learning opportunities as a result of contradictions both between and within activity systems. For example, the object of higher education activity systems (e.g., research publications in academic journals) and the traditional education values (e.g., competitive individualism) are likely to be in tension with the object of organizations in the not-for-profit sector (e.g., meeting community needs with limited resources) and values (e.g., social justice). As instructors and students work with community partners to resolve these contradictions, transformative changes can be sparked in individuals as well as in their respective organizations.

\section{CHAT as an Interventionist Research Method}

Following Vygotsky, CHAT research has interventionist aims-to encourage "expansive transformations" whereby the objects and motives of the activity are reconceptualized collectively to embrace a wider horizon of possibilities (Engeström, 2004, p. 150). This approach appeals to praxis-oriented research groups internationally-for example, the Laboratory for Comparative Human Cognition in San Diego, USA, the Centre for Activity Theory and Developmental Work in Helsinki, Finland, and the Centre for Human Activity Theory in Osaka, Japan. Expansive cycles of learning and development contain processes of internalization related to the reproduction of culture and externalization, when groups resolve contradictions in activity systems (Engeström, 1999; Engeström \& Miettinen, 1999). CHAT research methods combine the active participation of researchers with the monitoring of changes in participants, as exemplified in Worthen's (2008) study of garment workers' process of developing knowledge useful for navigating their workplace. Learning thus involved an increase in the individual or group's "action possibilities" (Roth et al., 2012). These analyses of everyday learning networks and the perspective of subordinated people provide insights into alternative spaces of knowledge production (Livingstone, 2006; Sawchuk, 2006).

CHAT is described as involving a "radical localism" based on the potential for change in every local activity of the society (Engeström, 1999). At the same time, an analysis of inner contradictions can provide insights into how larger sociopolitical and economic struggles mediate local practices, subjectivities, and learning (Roth \& Lee, 2007). Transformationnot simply adaptation-is at the core, since people are believed to come to know themselves and their world through the processes of collaboratively transforming it in view of their goals and purposes (Stetsenko, 2010). Reflecting its roots in a dialectical tradition, CHAT research is intended to become a part of the further development of the human practices being studied, rather than remaining outside those practices (Chailkin, 2012).

Still, it is important to note that tensions exist between more adaptive and transformative orientations within CHAT research (Fenwick et al., 2011). Sawchuk (2006) sug- 
gests, for example, that Engeström's concept of expansive learning "can never be fully achieved within the current institutional form of capitalist schooling" (p. 244). Other writers express similar concern about the continuity between activity theory and Marxist ideas because of conceptual slippage and neglect of wider patterns of social relations in which particular activity systems are located (Jones, 2009; Avis, 2009).

The diversity of CHAT approaches may also be positive for encouraging CSL programs-which seek to enlist higher education instructors across a diverse range of faculties and disciplines-to move beyond the dichotomous labels of traditional and critical (cf. Mitchell, 2008; Butin, 2006). Fundamentally, CHAT's praxis-oriented research is consistent with program goals of improving teaching and learning. It could also provide a model for CSL students working with community-partner organizations in learning networks that include instructors and community partners. Engagement in everyday learning networks encourages participants to challenge the "dominant (and dominating) ideologies that surround people's ideas about learning and their orientation to knowledge" (Sawchuk, 2006, p. 245).

\section{Concluding Comments}

The preceding discussion asserts that CHAT provides useful theoretical tools for thinking about CSL in terms of activity systems. Engeström's work, in particular, directs our attention to the intersecting activity systems involving students, instructors, and community partners in higher education and not-for-profit organizations. The four key assumptions of CHAT discussed above are consistent with the goals of CSL and help to reinforce it as a critical and reflexive pedagogy.

This paper arises from the recognition that, while Dewey and Freire are commonly discussed as influences in literature about CSL, CHAT references are noticeably absent. This is noteworthy, since some of the ideas associated with Dewey and Freire and CHAT coincide: for example, Dewey's belief that effective learning requires context through application and experience, and Freire's commitment to learning situations that are collaborative, active, community oriented, and grounded in the culture of the student. Engeström and Miettinen (1999) suggest that several ideas of pragmatists like Dewey have common features with activity theory.

However, subtle differences have also been discussed. For example, Guile (2010) argues that Dewey's view of reflection as a method for connecting theory to practice differs from Vygotsky's idea of reflection as a process that unifies theory and practice-Dewey viewed mind and world as "unified through transaction rather than constituted culturally and historically through human activity" (Guile, p. 82). Furthermore, writers question the attempt to reconcile activity theory with Dewey's pragmatism and the neo-pragmatism of writers like Rorty (Arce, 2006; Moraes, 2006). ${ }^{4}$ Further, Stetsenko (2008) argues that Freire provides a less-detailed account of the history of human development (anthropogenesis) and of individual development (ontogenesis) than do CHAT scholars, and undertheorizes the notion of human nature.

While more in-depth comparison of these thinkers would be beneficial, this paper has outlined key assumptions of CHAT in order to provide a pedagogical rationale for CSL programs and analytical tools that can be useful in research about and through CSL. CHAT confronts contradictions in activity systems by directing attention to the socio-po- 
litical and cultural-historical contexts in which individuals (including students, instructors, and community partners) are immersed, as well as the unique positioning and agency of these individuals vis-à-vis their contexts (Stetsenko \& Arievitch, 2004). It constructs service-learning as an activity that assumes an "inextricable link between practical and theoretical, material and mental, political and intellectual, social and individual" (p. 60). CHAT combines an ideological/ethical commitment to social change along with an historical materialist commitment to studying phenomena as they unfold (Stetsenko, 2008).

In addition to providing tools for academic researchers, CHAT provides important tools for CSL students and other participants to reflect on their experiences. For example, analyzing differences in the objectives, rules, norms, mediating artifacts, and division of labour across different activity systems is an essential first step toward engaging in the creation, development, and transformation of their learning and working conditions.

\section{Endnotes}

1 Chailkin (2012) suggests that the dialectical tradition with which CHAT is associated "cuts across the disciplinary boundaries (which originated in the nineteenth century) that differentiate the social sciences in the twenty-first century. For example, psychology is usually understood as the study of individuals; sociology the study of groups in society" (p. 36).

2 CHAT research varies widely in the extent to which it engages with Marxist ideas. Sawchuk et al.'s (2006) book was written partly to promote more critical engagement with these ideas. It is consistent with concerns of writers like Jones (2009) and Avis (2009) about the neglect of wider patterns of social relations in which particular activity systems are located in some of the CHAT literature. Engeström and Miettinen (1999) also include chapters that address the relevance for CHAT of Antonio Gramsci's ideas (Colucci, 1999) and Bourdieu's ideas (Hayrynen, 1999); Daniels (2004, 2012) also draws on Bernstein, known for his sociolinguistic theory of language codes, to inform CHAT. But it is fair to say that paradigmatic tensions persist between more adaptive and transformative orientations within CHAT work (Fenwick et al., 2011).

3 Cautions about the growing emphasis within government policies on a privatized knowledge market are voiced by critics, who argue that knowledge should be seen as a gift exchange involving the circulation of ideas rather than as a commodity exchange (Bullen, Robb, \& Kenway, 2004; Kenway, Bullen, \& Robb, 2004).

4 For example, Maria Marcondes de Moraes (2006) suggests that Rorty exhibits epistemological skepticism and hyper-contextualism and thus fails to challenge the depoliticization of education.

\section{References}

Arce, A. (2006). The importance of play in pre-school education. In P. Sawchuk, N. Duarte, \& M. Elhammoumi (Eds.), Critical perspectives on activity: Explorations across education, work, and everyday life (pp. 75-88). Cambridge: Cambridge University Press.

Akkerman, S., \& Bakker, A. (2011) Boundary crossing and boundary objects. Journal of Educational Research, 81(2), 132-169. 
Avis, J. (2009). Transformation or transformism? Engeström's version of activity theory. Educational Review, 61(2): 151-165.

Beach, K. (1999). Beyond transitions: A sociocultural expedition beyond transfer in education. Review of Research in Education, 24, 101-39.

Bringle, R., \& Hatcher, J. (1996). Implementing service-learning in higher education. Journal of Higher Education, 67(2), 221-239.

Bullen, E., Robb, S., \& Kenway, J. (2004). 'Creative destruction': Knowledge economy policy and the future of the arts and humanities in the academy. Journal of Education Policy, 1: 3-22.

Butin, D. (2006). The limits of service-learning in higher education. Review of Higher Education, 29(4): 473-498.

Butin, D. (2007, Nov/Dec). Focusing our aim: Strengthening faculty commitment to community engagement. Change: $34-37$.

Butin, D. (2010). Service-learning in theory and practice: The future of community engagement in higher education. Hampshire UK: Palgrave Macmillan.

Chailkin, S. (2012). Dialectics, politics and contemporary cultural-historical reseach, exemplified through Marx and Vygotsky. In H. Daniels (Ed.), Vygotsky and sociology (pp. 24-43). London: Routledge.

Chambers, T. (2009). A continuum of approaches to service-learning within Canadian post-secondary education. Canadian Journal of Higher Education, 39(2): 77-100.

Charbonneau, L. (2009, September 8). Community connections. University Affairs. Retrieved from www.universityaffairs.ca

Chovanec, D., Kajner, T., Mian, A., Underwood, M. (2012). Exploring shifts in conceptions of "good" citizenship: Community service-learning in activist placements. Cultural and Pedagogical Inquiry, 4(1): 43-56.

Colucci, F. (1999). The relevance to psychology of Antonio Gramsci's ideas on activity and common sense. In Y. Engeström, R. Miettinen, \& R. Punamaki, (Eds.), Perspectives on activity theory. (pp. 147-162). Cambridge: Cambridge University Press.

Daniels, H. (2004). Activity theory, discourse and Bernstein. Educational Review, 56(2): 121-132.

Daniels, H. (Ed.). (2012). Vygotsky and sociology. London: Routledge.

Deans, T. (1999). Service-learning in two keys: Paulo Freire's critical pedagogy in relation to John Dewey's pragmatism. Michigan Journal of Community Service Learning, 15-29.

Edwards, A., \& Mackenzie, L. (2005). Steps towards participation: The social support of learning trajectories. International Journal of Lifelong Education, 24(4), 287-302.

Engeström, Y. (1987). Learning by expanding: An activity-theoretical approach to developmental research. Helsinki: Orienta-Konsultit.

Engeström, Y. (1999). Activity theory and individual and social transformation. In Y. Engestrom, R. Miettinen, \& R. Punamaki. (Eds.). Perspectives on activity theory (pp. 19-38). Cambridge: Cambridge University Press. 
Engström, Y. (2004). The new generation of expertise: Seven theses. In H. Rainbird, A. Fuller, \& A. Munro (Eds.), Workplace learning in context (pp. 145-65). London: Routledge.

Engeström, Y. (2008). From teams to knots: Activity-theoretical studies of collaboration and learning at work. Cambridge: Cambridge University Press.

Engeström, Y., \& Miettinen, R. (1999). Introduction. In Y. Engestrom, R. Miettinen \& R. Punamaki. (Eds.), Perspectives on activity theory (pp. 1-16). Cambridge: Cambridge University Press.

Fenwick, T., Edwards, R., \& Sawchuk, P. (2011). Emerging approaches to educational research. London: Routledge.

Fredericksen, P. (2000). Does service learning make a difference in student performance? Journal of Experiential Learning, 23(2), 64-74.

Furco, A. (1996). Service learning: A balanced approach to experiential education. Expanding boundaries: service and learning. Washington, DC, Corporation for National Service: $2-6$.

Guile, D. (2010). The learning challenge of the knowledge economy. Rotterdam: Sense.

Guile, D., \& Griffiths, T. (2001). Learning through work experience. Journal of Education and Work, 14, 113-131.

Guile, D., \& Young, M. (2003). Transfer and transition in vocational education: Some theoretical considerations. In Y. Engeström \& T. Gronin (Eds.), Between work and school: New perspectives on transfer and boundary-crossing. London: Pergamon, pp. 63-81.

Hayrynan, V. (1999). Collapse, creation and continuity in Europe: How do people change? In Y. Engestrom, R. Miettinen, \& R. Punamaki (Eds.), Perspectives on activity theory (pp. 115-132). Cambridge: Cambridge University Press.

Hugg, R., \& Wurdinger, S. (2007). A practical and progressive pedagogy for projectbased service learning. International Journal of Teaching and Learning in Higher Education, 19(2), 191-204.

Jackson, E. (2008, September). The CUE factor: Community-university engagement for social innovation. Technology Innovation Management Review. Retrieved from http://www.timreview.ca/article/189

Jones, P. (2009). Breaking away from theorizing activity in the shadow of Marx. Outlines, 1: 45-58.

Kajner, T., Chovanec, D., Underwood, M., \& Mian, A. (2013, Spring). Critical community service learning: Combining critical classroom pedagogy with activist community placements. Michigan Journal of Community Service Learning, 36-48.

Kenway, J., Bullen, E., \& Robb, S. (2004). The knowledge economy, the technopreneur, and the problematic future of the university. Policy Futures in Education, 2(2): 330-349.

Kolb, D. (1984). Experiential Learning: Experience as the source of learning and development. New Jersey: Prentice Hall. 
Livingstone, D. (2006). Contradictory class relations in work and learning. In P. Sawchuk, N. Duarte, \& M. Elhammoumi (Eds.), Critical perspectives on activity: Explorations across education, work, and everyday life (pp 145-159). Cambridge: Cambridge University Press.

Lompscher, J. (2006). The cultural-historical activity theory: Some aspects of development. In P. Sawchuk, N. Duarte, \& M. Elhammoumi (Eds.), Critical perspectives on activity: Explorations across education, work, and everyday life (pp. 35-51). Cambridge: Cambridge University Press.

McDermott, R., \& Lave, J. (2006). Estranged labor learning. In P. Sawchuk, N. Duarte, \& M. Elhammoumi (Eds.), Critical perspectives on activity: Explorations across education, work, and everyday life (pp. 89-122). Cambridge: Cambridge University Press.

Miettinen, R. (1999). Transcending traditional school learning: Teachers' work and networks of learning. In Y. Engestrom, R. Miettinen \& R. Punamaki (Eds.). Perspectives on activity theory (pp. 325-344). Cambridge: Cambridge University Press.

Miettinen, R., \& Peisa, S. (2002), Integrating school-based learning with the study of change in working life: the alternative enterprise method. Journal of Education and Work, 15(3): 303-319.

Mitchell, T. (2008, Spring). Traditional vs. critical service-learning: Engaging the literature to differentiate two models. Michigan Journal of Community Service Learning: $50-65$.

Moraes, M. (2006). Epistemological skepticism, complacent irony. In P. Sawchuk, N. Duarte, \& M. Elhammoumi (Eds.). Critical perspectives on activity: Explorations across education, work, and everyday life (pp. 52-71). Cambridge: Cambridge University Press.

Niewolny, K., \& Wilson, A. (2009). What happened to the promise? A critical (re) orientation of two sociocultural learning traditions. Adult Education Quarterly, 6o(1): $26-45$.

Roth, W., \& Lee, Y-J. (2007). "Vygotsky's neglected legacy": Cultural-historical activity theory. Review of Educational Research, 77(2): 186-232.

Roth, W., Radford, L., \& LaCroix, L. (2012). Working with cultural-historical activity theory [57 paragraphs]. Forum Qualitative Sozialforschung/Forum Qualitative Social Research, 13(2). Retrieved from http://nbn-resolving.de/urn:nbn:de:0114-fqs1202232

Saltmarsh, J., Hartley, M., \& Clayton, P. (2009). Democratic engagement white paper. New England Resource Centre for Higher Education. Retrieved from http:// futureofengagement.files.wordpress.com/2009/02/democratic-engagement-whitepaper-2_13_09.pdf

Sawchuk, P. (2006). Activity and power: Everyday life and development of workingclass groups. In P. Sawchuk, N. Duarte, \& M. Elhammoumi (Eds.). Critical perspectives on activity: Explorations across education, work, and everyday life (pp. 238-267). Cambridge: Cambridge University Press. 
Sawchuk, P., Duarte, N., \& Elhammoumi, M. (Eds.). (2006). Critical perspectives on activity: Explorations across education, work, and everyday life. Cambridge: Cambridge University Press.

Stetsenko, A. (2008). From relational ontology to transformative activist stance on development and learning: Expanding Vygotsky's (CHAT) project. Cultural Studies of Science Education, 3: 471-491.

Stetsenko, A. (2010). Teaching-learning and development as activist projects of historical becoming: Expanding Vygotsky's approach to pedagogy. Pedagogies: An International Journal, 5(1): 6-16.

Stetsenko, A., \& Arievitch, I. (2004). Vygotskian collaborative project of social transformation: History, politics and practice in knowledge construction. Critical Psychology, 12(4): 58-80.

Toulmin, S. (1999). Knowledge as shared procedures. In Y. Engestrom, R. Miettinen, \& R. Punamaki (Eds.), Perspectives on activity theory (pp. 53-64). Cambridge: Cambridge University Press.

Vygotsky, L.S. (1978). Mind and society: The development of higher psychological processes. Cambridge, MA: Harvard University Press.

Worthen, H. (2008). Using activity theory to understand how people learn to negotiate the conditions of work. Mind, Culture, and Activity, 15(4): 322-338.

\section{Acknowledgement}

I gratefully acknowledge funding support from the Social Sciences and Humanities Research Council and from a Killam Cornerstone Grant, University of Alberta, for this research. Thank you also to Milosh Raykov for his help with the literature review.

\section{Contact Information}

Alison Taylor

Department of Educational Policy Studies

University of Alberta

ataylor@ualberta.ca

Alison Taylor is a professor of education and the Director of Community-Service-Learning at the University of Alberta. She is the author of several articles about school-to-work transitions and youth apprenticeship. Her current work focuses on experiential learning in higher education contexts. 